\title{
Eales disease
}

INSERM

\section{Source}

INSERM. (1999). Orphanet: an online rare disease and orphan drug data base. Eales disease. ORPHA:40923

Eales disease (ED) is an idiopathic, inflammatory retinal venous occlusive disease characterized by 3 stages: vasculitis, occlusion and retinal neovascularization, leading to recurrent vitreous hemorrhages and vision loss. 